\title{
İlköğretim 6-8. Sinlf Öğretmenlerinin Ölçme-Değerlendirme Yöntemlerine Bakış Açıları, Kullanım Kriterleri ve Karşılaştıkları Problemler: Erzurum Örneklemi ${ }^{3}$
}

\author{
Fatih YAZICI \\ Âşlk Yaşar Reyhani Ortaokulu, Palandöken/Erzurum \\ E-mail: fatyaz@mynet.com \\ Mustafa SÖZBILIIR \\ Atatürk Üniversitesi Kazım Karabekir Eğitim Fakültesi, Yakutiye/ Erzurum \\ E-mail: sozbilir@atauni.edu.tr
}

\begin{abstract}
$\ddot{O}_{z e t}$
Bu çalı̧̧manın amacı ilköğretim 6-8. sinıf öğretmenlerinin ölçme değerlendirme yöntemlerine ilişkin bakış açılarını ve kullanacakları ölçme-değerlendirme araç-gereç ve yöntemleri neye göre belirlediklerini tespit edip, bu alanda karşılaşılan sorunları belirleyerek bu sorunların çözümüne yönelik neler yapılabileceğini ortaya koymaktır. Çalışma, nicel araştırma yaklaşımlarından tarama yöntemiyle yürütülmüss, veriler araştırmacı tarafindan geliştirilen anket formu ile toplanmıştır. Araştırmanın evreni, Erzurum il merkezi ilkögrretim okullarındaki 6-8. sinıflarda görevli 1470 branş öğretmenidir. Örneklem oluşturulurken olasllkklı (tesadüfi) olmayan örnekleme yöntemlerinden elverişlilik örneklemesi kullanılmıştır. Bu bağlamda araştırmanin örneklemi 2011-2012 eğitim-öğretim yllında Erzurum il merkezi ilköğretim okullarındaki 6-8. sinıflarda görevli 474 branş öğretmeninden oluşmaktadır. Araştırma sonucunda; öğretmenlerin ölçme değerlendirme yöntemlerine ilişkin hem olumlu hem de olumsuz bakış açılarının olduğu, kullanacakları yöntemleri belirlerken en fazla ögrrenci seviyesini, en az ise idareci ve velilerin tercihlerini dikkate aldıklarl, kullanım sırasında en fazla karşılaş̧tıkları problemin ise mevcut altyapı eksikliği olduğu tespit edilmişstir. Ögretmenler bu konudaki sorunların giderilmesi için alternatif ölçme-değerlendirme araç-gereç ve yöntemleri ile ilgili çallş̧malara ve eğitim fakülttelerinde ölçme-değerlendirmeye yönelik derslere ağırlı verilmesi gerektiğini belirtmişler, ayrıca teorikten ziyade uygulamaya dönük hizmet içi eğitim kurslarının düzenlenmesi gerektiğini vurgulamışlardır.
\end{abstract}

Anahtar Kelimeler: Alternatif ölçme-değerlendirme, anket, müfredat uygulama, öğretmen, ölçmedeğerlendirme, tarama.

\section{Elementary 6-8 Grades Teachers' Views on Assessment and Evaluation Methods, Criteria of Use and Problems Encountered: Erzurum Sampling}

\begin{abstract}
The aim of this study is to find out elementary 6-8 grades teachers' views on assessment and evaluation methods, to identify the criteria they apply in selecting these methods to use, problems encountered with the assessment and evaluation and how to solve these problems. Data were collected in 2011-12 academic year through a questionnaire developed by the researchers in this survey study. 474 teachers were selected through a convenience sampling method based on voluntary participation from a total of 1770 teachers teaching grades 6 to 8 from schools in Erzurum city center. Result indicated that teachers have both positive
\end{abstract}

\footnotetext{
${ }^{3}$ Bu çalışma Fatih YAZICI'nın yüksek lisans tezinin bir bölümüdür.
} 
and negative perspectives concerning methods of assessment and evaluation. It is found that the most influential factors in deciding assessment evaluation methods to use were students' levels, parents and administrates views. Moreover, the most common problem encountered regarding the assessment and evaluation was the lack of necessary infrastructure, knowledge on alternative assessment and evaluation methods and technical support for the teachers. In order to solve these problems, teachers suggested that there must be more emphasize should be given during preservice teacher training and also in-service training for the teachers.

Keywords: Alternative assessment and evaluation, assessment and evaluation, curriculum implementation, questionnaire, survey, teachers.

\section{Giriş}

Eğitim, öğrencinin davranışlarında kendi yaşantısı yoluyla ve kasıtlı olarak istendik değişme meydana getirme sürecidir (Ertürk, 1994). Buna göre, öğretimin daha önceden belirlenen amaçları gerçekleştirip gerçekleştirmediğinin anlaşılabilmesi için öğrencilerde meydana gelen davranış değişikliklerinin ölçülüp değerlendirilmesi gerekir. Ancak öğrencilere bir davranışı yapma firsatı verilmeden o davranışın öğrencide gelişip gelişmediğinin anlaşılması imkânsızdır. Bunun için öğrenciler o davranışı gösterme olanağı verecek hatta o davranışı yapmaya itecek test durumları içine sokulmalıdır. Düzenlenecek test durumları şüphesiz gözlenecek davranışla ilgili olmalıdır. Bu nedenle gözlenecek davranışa göre çok çeşitli ölçme araçları kullanılması kaçınılmazdır (Tekin, 2004).

Son yıllarda dünyada ve ülkemizde değişen eğitim anlayışı bilginin öğretmen merkezli değil, tamamen öğrenciyi merkeze alan, öğretmenin bu süreçte yalnızca rehber olduğu bir anlayış getirmiştir. $\mathrm{Bu}$ anlayışa göre oluşturulmuş yeni öğretim programlarında geleneksel eğitim programlarından farklı olarak yeni öğrenme süreçleri, yeni öğrenme ve öğretme etkinlikleri ortaya çıkmış ve bunun sonucunda ölçme-değerlendirme yaklaşımları da farklılaşmıştır (Fourie ve Van Niekerk, 2001).

Yenilenen öğretim programlarının tasarlanmasında etkili olan yapılandırmacı yaklaşıma göre, her öğrenci daha önceden sahip olduğu bilgi, tutum, değer ve alışkanlıklarına göre öğretilmeye çalışılan bilgiye kendine özgü anlamlar yükler. Dolayısıyla bireye özgü olan bu öğrenmelerin sadece yazılı yoklamalar ve çoktan seçmeli testlerle ölçülebilmesi mümkün değildir. Örneğin; günümüz öğretim programlarında yer alan yaratıcı ve eleştirel düşünme, problem çözme, karar verme, araştırma ve girişimcilik gibi ortak becerilerin ne ölçüde kazanıldığının ölçülüp değerlendirilmesinde sınırlandırılmış, tek yanıtlı çoktan seçmeli testlerin kullanılması doğru bir yöntem olmaz. Bunun yanında alternatif ölçme araçları olarak adlandırılan gözlem, poster, proje, performans gibi öğrenciyi tüm yönlerden değerlendirme firsatı sunan araçların da kullanılması daha isabetli olacaktır. Tüm bunlardan yola çıkarak öğrenme amaçlarının giderek daha karmaşık bir hal alması ve buna bağlı olarak kullanılan ölçme-değerlendirme araç-gereç ve yöntemlerinin çeşitliliğinin artması, ölçme ve değerlendirme sürecinin daha karmaşık bir hal almasına neden olmaktadır (Semerci, 2008).

Metin ve Özmen (2010) tarafından yapılan araştırmada öğretmenlerin özellikle ölçme değerlendirme uygulamalarının nasıl yapılması ve değerlendirilmesi gerektiği konusunda sorun yaşadıkları ve bu konuda yardıma ihtiyaç duydukları belirlenmiştir. Özellikle öğretmenlerin kullanmak istedikleri yöntemle ilgili olan ölçeklerin hazırlanması, kriterlerin belirlenmesi ve mevcut ölçeklerin nerede, nasıl ve hangi amaçlar için kullanılması gerektiğinin bilinmemesi noktasında birçok sorunla karşılaştıkları belirlenmiştir (Benzer ve Eldem, 2013; Gelbal ve Kelecioğlu, 2007; Sağlam Arslan, Devecioğlu Kaymakçı ve Arslan, 2009; Şenel Çoruhlu, Er Nas ve Çepni, 2009). Bu gibi sorunların yaşanmasında mevcut imkânların yetersizliği, sınıfların kalabalık oluşu, zaman yetersizliği, hazırlama-uygulama ve değerlendirme zorluğu, yöntemlerin karmaşıklığı ve sınıf düzeyine uygun olmayışı, öğretmenlerin, öğrencilerin ve velilerin yöntemlere karşı teorik ve özellikle pratik bilgilerinin azlı̆̆ uygulanan sınav sistemlerinin yöntemlerle uyumsuzluğu, MEB tarafından yürütülen hizmet içi eğitimlerin yetersizliği gibi birçok faktörün etkili olduğu yapılan araştırmalarca ortaya koyulmuştur (Büyüktokatlı ve Bayraktar, 2014; Cansız Aktaş ve Baki, 2013; Gelbal ve Kelecioğlu, 2007; Gömleksiz, Yıldırım ve Yetkiner, 2011; Metin ve Demiryürek, 2009; Özdemir, 2009; Sağlam Arslan vd., 2009). 
Akbaş ve Gençtürk (2013) tarafından yapılan araştırmada öğretmenlerin \%65,7'si alternatif ölçme değerlendirme tekniklerinin genelde uygulanabilir olduğunu, \%25'inin çok az ya da hiç uygulanamayacağını, \%9.2'sinin ise bu tekniklerin tamamının uygulanabilir olduğunu belirtmişlerdir. Ayrıca geleneksel ölçme-değerlendirme tekniklerinin belirli oranda sınırlılıkları olduğunu, fakat alternatif tekniklerin de genel olarak hazırlık sürecinde zorlukların yaşanması, uygulama ve değerlendirme sürecinin uzun zaman alması gibi sınırlılıklarının olduğunu ifade etmişlerdir. Bunun yanında Metin ve Demiryürek (2009) araştırmalarında Türkçe öğretmenlerinin büyük bir çoğunluğunun alternatif ölçme-değerlendirme anlayışı hakkında yeterli bilgiye sahip olmadığını özellikle de performans ve projenin nasıl yapıldığını bilmediklerini ortaya koymuştur. Ayrıca öğretmenlerin yeni değerlendirme anlayışına yönelik olumlu bir bakış açısına sahip oldukları da belirlenmiştir. Yine Duban ve Küçükyılmaz (2008) tarafından yapılan araştırmada sınıf öğretmeni adayları alternatif ölçme-değerlendirme yöntem ve tekniklerine olumlu yaklaşmış, birçoğu çeşitli öğretim programlarında önerilen alternatif ölçme-değerlendirme yöntem ve tekniklerinin objektif olduğunu ve öğrenciyi değişik yönleriyle değerlendirme fırsatı sunduğunu belirtmişlerdir. Şahin ve Abalı Öztürk (2014) ise yaptıkları araştırmada sınıf öğretmeni adaylarının \%77'sinin alternatif, \%23'ünün ise geleneksel ölçme değerlendirme yöntemlerini meslek hayatlarına başladıklarında kullanmayı düşündüklerini ifade etmişlerdir. Ayrıca öğretmen adayları tarafından en çok tercih edilen alternatif yöntemin portfolyo (öğrenci ürün dosyaları), geleneksel yöntemin ise çoktan seçmeli testler olduğu ortaya çıkarılmıştır. Araştırmada öğretmen adayları, ilkokulların çoğunda öğrencilerin bireysel farklılıklarının dikkate alınmadığı, süreçten ziyade ürüne dayalı ve üst düzeyindeki kazanımları ölçmede yetersiz olan bir ölçme değerlendirme anlayışının hâkim olduğunu düşünmektedirler.

Fizik, kimya ve matematik öğretmenlerinin değerlendirme araçları/uygulamaları ile ilgili bilgi düzeyleri, yaklaşımları ve bu araçları kullanma alışkanlıklarını incelemek amacıyla yapılan araştırmada geleneksel değerlendirmenin yanı sıra alternatif uygulamalara da önem verildiğini ancak öğretmenlerin bu konuda hem fikir olamadığ 1 ve öğretmenler tarafından en az güven duyulan araçların alternatif değerlendirme araçları olduğu görülmüştür (Nazlıçiçek ve Akarsu, 2008). Ayrıca araştırmada öğretmenlerin en az kullandıkları uygulamaların alternatif ölçme-değerlendirme uygulamaları olduğu görülmüss, bu durumun sebebi olarak da öğretmenlerin alternatif yöntemler hakkında yeterli bilgiye sahip olmadıkları ve bu yöntemlere güven duymayıp gereken önemi göstermedikleri ileri sürülmüştür. Şahin, Boztunç Öztürk ve Taşdelen Teker'in (2015) çeşitli branşlardan 163 öğretmen adayı üzerinde yaptıkları araştırmada ise öğretmen adaylarının kendi başarılarının değerlendirilmesinde kendilerine sunulan sekiz ölçme değerlendirme aracından en çok doğru-yanlış testlerini, en az da performans görevlerini tercih etmişlerdir. Ayrıca sekiz farklı ölçme değerlendirme aracı öğretmen adaylarının tercihlerine göre sıralandığında geleneksel araçlarının alternatif araçlara göre daha üst sıralarda olduğu ortaya çıkarılmıştır. Araştırmadan elde edilen bulgulardan hareketle öğretmen adaylarının kendi başarılarının değerlendirilmesinde daha çok geleneksel yaklaşımları tercih etmelerinin ileride öğretmenlik mesleğini icra ederken de bu araçları kullanmaya meyilli olacakları yönünde yorumlanmıştır. Altun ve Gelbal (2014) da yaptıkları araştırmada ilköğretim öğretmenlerin sekiz farklı alternatif ölçme değerlendirme yönteminden en çok kullandıkları yöntemleri araştırmış ve bu yöntemlerin en çok kullanılandan en az kullanılana doğru sırasıyla performans, görüşme, gözlem, akran değerlendirme, öz değerlendirme, öğrenci ürün dosyası, grupla değerlendirme ve günlük olduğunu ortaya çıkarmışlardır. Dokumaci Sütçü ve Bulut (2015) tarafından yapılan araştırmada ise matematik öğretmenlerinin alternatif ölçme ve değerlendirme tekniklerine ilişkin yeterlik algıları ve bu teknikleri kullanma sıklıklarının cinsiyet ve hizmet içi eğitim alma durumlarına göre anlamlı bir farklılaşma göstermediği, kıdeme göre ise anlamlı derecede farklılaştığı ortaya çıkarılmıştır. Buna göre 16 yıl ve üzeri kıdeme sahip matematik öğretmenlerinin alternatif ölçme ve değerlendirme tekniklerine ilişkin yeterlilik düzeyleri ve bu teknikleri kullanım sıklıkları daha yüksek çıkmıştır. Ayrıca her ne kadar anlamlı bir farklılık olmasa da bayan öğretmenler alternatif ölçme ve değerlendirme tekniklerine ilişkin kendilerini erkeklere göre daha az yeterli görmelerine rağmen bu teknikleri daha sık kullanmışlardır. Benzer şekilde hizmet içi eğitim alan öğretmenlerin almayanlara göre alternatif ölçme ve değerlendirme tekniklerine ilişkin kendilerini daha yeterli gördüğü ve bu teknikleri daha sık kullanmakta olduğu belirtilmiştir. 
Yapılan araştırmalarda ölçme değerlendirme konusunda yaşanan problemleri ortadan kaldırmak için; ölçme-değerlendirme yöntemlerini layıkıyla kullanma ve uygun ölçek hazırlayabilme konusunda öğretmenlere eğitim verilmesi, hazır geliştirilmiş çok sayıda ve çeşitte ölçeklerin kullanıma sunulması, öğretmen adayları için eğitim fakültelerinde ölçme değerlendirmeye yönelik derslere daha fazla ağırlık verilmesi ve öğretmenlerin bulundukları bölge veya okulda ölçme değerlendirme uzmanının bulundurulması gibi öneriler sunulmuştur (Cansız Aktaş ve Baki, 2013; Fidan ve Sak, 2012; Gelbal ve Kelecioğlu, 2007; Metin ve Özmen, 2010; Nazlıçiçek ve Akarsu, 2008; Özenç, 2013; Şenel Çoruhlu vd., 2009; Tuncer ve Y1lmaz; 2012).

\subsection{Araştırmanın önemi ve amacı}

Çalışmanın, yenilenen öğretim programlarında ölçme-değerlendirme alanındaki sorunların saptanması, saptanan sorunların giderilmesine yönelik yapılacak çalışmaların belirlenmesi ve bu sayede hem alan yazına bir katkı sağlaması, hem de öğretmenlerin bu konudaki eksiklikleri belirlenerek öğrenme ihtiyaçlarının tespitine yardımcı olması beklenmektedir.

$\mathrm{Bu}$ çalışmanın amacı Erzurum merkez ilçelerde görev yapan ilköğretim 6-8. sınıf öğretmenlerinin ölçme-değerlendirme yöntemlerine ilişkin bakış açılarını ve kullanacakları yöntemleri belirleme ölçütlerini tespit edip, bu alanda karşılaşılan sorunları belirleyerek çözüme yönelik neler yapılabileceğini ortaya koymaktır. Bu amaç doğrultusunda aşağıdaki sorulara cevap aranmıştır:

1. İlköğretim 6-8. sınıf öğretmenlerinin ölçme-değerlendirme araç-gereç ve yöntemlerine ilişkin bakış açıları nasıldır?

2. İlköğretim 6-8. sınıf öğretmenleri kullanacakları ölçme-değerlendirme araç-gereç ve yöntemlerini neye göre belirlemektedir?

3. İlköğretim 6-8. sınıf öğretmenlerinin ölçme-değerlendirme araç-gereç ve yöntemlerini kullanırken karşılaştıkları problemler nelerdir?

4. İlköğretim 6-8. sınıf öğretmenlerinin ölçme-değerlendirme araç-gereç ve yöntemlerine ilişkin yaklaşımlarını geliştirmek için ne tür önlemler alınabilir?

\section{Yöntem}

\subsection{Araştırma modeli}

Çalışmada, herhangi bir konu ya da olaya ilişkin bireylerin görüş, ilgi, beceri, yetenek ya da tutum gibi özelliklerin belirlendiği, genellikle göreceli olarak daha büyük örneklemler üzerinde yürütülen bir nicel araştırma yaklaşımı olan tarama araştırması yapılmıştır (Büyüköztürk, Kılıç Çakmak, Akgün, Karadeniz ve Demirel; 2010). Tarama araştırmalarının amacı olay ya da olguların oluş sıklıklarını, özelliklerini ve üzerinde etkili olan faktörleri önem derecesine göre belirlemek ve değişkenler arasındaki ilişkileri tespit ederek genellemelere varmaktır (İslamoğlu, 2009). Bu tür araştırmalarda, evreni yeterince temsil edebilecek örneklem oluşturularak çok sayıda kişiye ulaşılır ve katılımcılardan betimsel nitelikte veriler elde edilir. Elde edilen bulgular diğer araştırmalar için bir veri kaynağıdır ve bu bulgulara dayanılarak diğer araştırmalar için varsayımlar geliştirilebilir (Aziz, 2008).

\subsection{Evren ve örneklem}

Araştırmanın evrenini, Erzurum il merkezi ilköğretim okullarındaki 6-8. sınıflarda görevli 1470 branş öğretmeni oluşturmaktadır. Örneklem oluşturulurken olasılıklı (tesadüfî) olmayan örnekleme yöntemlerinden elverişlilik örneklemesi kullanılmıştır (Böke, 2009). Elverişlilik örneklemesi ile isteyen herkes örnekleme dâhil edilmiş, zaman ve maliyet açısından çok ekonomik olduğundan araştırmaya hız ve pratiklik kazandırılmıştır. Evrendeki tüm öğretmenlere çalışmaya katılmaları için davetiye gönderilmiş fakat çalışmaya gönüllü olarak katılmak isteyen öğretmenlerden veri toplanmıştır. Bu yönteme göre 2011-2012 eğitim-öğretim yılında Erzurum il merkezine bağlı Aziziye 
merkez ilçesinden 11, Yakutiye merkez ilçesinden 31 ve Palandöken merkez ilçesinden 26 olmak üzere toplam 68 ilköğretim okulunda 6-8. sınıflarda görevli 474 branş öğretmeni çalışmaya gönüllü olarak katılmayı kabul etmiştir ve araştırmanın örneklemini oluşturmuştur. Araştırmaya katılan öğretmenlerin demografik özelliklerine ilişkin bilgiler Tablo 1'de gösterilmektedir.

Tablo 1. Örnekleme Ait Betimsel Veriler

\begin{tabular}{|c|c|c|c|c|c|}
\hline İlçe Adı & f & $\%$ & Yaş Aralığı & f & $\%$ \\
\hline Aziziye & 73 & 15.4 & $20-25$ & 46 & 9.7 \\
\hline Yakutiye & 198 & 41.8 & $26-30$ & 163 & 34.4 \\
\hline Palandöken & 203 & 42.8 & $31-40$ & 175 & 36.9 \\
\hline Toplam & 474 & 100.0 & $41-50$ & 47 & 9.9 \\
\hline Okul türü & & & 51 ve üzeri & 42 & 8.9 \\
\hline Devlet & 441 & 93.0 & Yaş Belirtmeyen & 1 & 0.2 \\
\hline Özel & 33 & 7.0 & Toplam & 474 & 100.0 \\
\hline Toplam & 474 & 100.0 & \multicolumn{3}{|l|}{ Kıdem Aralığı } \\
\hline Branş & & & $1-5 \mathrm{y} 11$ & 132 & 27.8 \\
\hline Matematik & 77 & 16.2 & $6-10$ y1l & 164 & 34.6 \\
\hline Türkçe & 107 & 22.6 & $11-15 \mathrm{y} 1 \mathrm{l}$ & 66 & 13.9 \\
\hline Fen ve Teknoloji & 83 & 17.5 & $16-20$ y1l & 53 & 11.2 \\
\hline Sosyal Bilgiler & 64 & 13.5 & $21-25$ y1l & 15 & 3.2 \\
\hline İngilizce & 99 & 20.9 & 26 ve üzeri yıl & 37 & 7.8 \\
\hline Din Kültürü ve Ahlak Bilgisi & 21 & 4.4 & Kidem Belirtmeyen & 7 & 1.5 \\
\hline Diğer & 8 & 1.7 & Toplam & 474 & 100.0 \\
\hline Branş Belirtmeyen & 15 & 3.2 & & & \\
\hline Toplam & 474 & 100.0 & & & \\
\hline \multicolumn{6}{|l|}{ Cinsiyet } \\
\hline Bayan & 241 & 50.8 & & & \\
\hline Erkek & 227 & 47.9 & & & \\
\hline Cinsiyet Belirtmeyen & 6 & 1.3 & & & \\
\hline Toplam & 474 & 100.0 & & & \\
\hline
\end{tabular}

\subsection{Veri toplama araçları}

Araştırma kapsamında belirlenen soruları yanıtlamak için araştırmacı tarafından geliştirilen “İlköğretim 6-8 sınıflardaki branş öğretmenlerinin ölçme-değerlendirme araçlarını kullanma durumları anketi', kullanılmıştır.

Araştırmada kullanılan anketin güvenirliği ve geçerliği kapsamında anketteki maddelerin saptanması amacıyla alan yazın taraması sonucu öğretmenlerin ölçme-değerlendirme yöntemlerinin hangi boyutlarına yönelik görüş bildirecekleri tespit edilmeye çalışılarak bir madde havuzu oluşturulmuştur. Madde havuzundan yararlanılarak hazırlanan anket taslağı, ölçme-değerlendirme ve program geliştirme bilim dalından ikişer akademisyene ve ilköğretim okullarında görev yapan 3 öğretmene inceletilmiş, gelen öneriler doğrultusunda gerekli düzeltmeler yapılmıştır. Ayrıca anket 2 dil uzmanı tarafından kontrol edilmiş, maddelerin anlaşılabilirliği ve okunabilirliği hakkında yapılan yorumlara göre anket yeniden gözden geçirilmiştir. Son olarak anketin pilot uygulaması gerçekleștirilmiş ve bazı bölümlerde gereken değişiklikler yapılmıştır. Anket, Erzurum İl Milli Eğitim Müdürlüğü'nden izin alınarak çalışma kapsamındaki ilköğretim okullarında görevli toplam 474 öğretmene gönüllülük esasına göre bizzat araştırmacının kendisi tarafından uygulanmıştır.

\subsection{Verilerin analizi ve kullanılan istatistiksel teknikler}

Araştırmada öğretmenlerin demografik özelliklerini, araç-gereç ve yöntemlere ilişkin bakış açılarını, kullanacakları ölçme-değerlendirme araç-gereç ve yöntemleri belirleme ölçütlerini, bu yöntemleri kullanırken karşılaştıkları problemleri ve çözüm önerilerini belirlemek için elde edilen verilerin 
analizinde betimsel istatistiklerden frekans (f) ve yüzde (\%) kullanılarak genel durum betimlenmiş ve bakış açılarına ilişkin görüşlerinin ortalamaları hesaplanmıştır. Ayrıca her bölümde "diğer" seçeneği altında belirtilen görüşler içerik analizi yaklaşımı kullanılarak tek tek incelenmiş, aynı anlamda olan ifadeler gruplaştırılmış ve tüm ifadeler tablolar halinde frekanslarıyla (f) birlikte sunulmuştur. Tüm bu analizler bilgisayar ortamında SPSS 18 (PASW Statistics 18) programı kullanılarak yapılmıştır.

\section{Bulgular}

$\mathrm{Bu}$ bölümde öğretmenlerin ölçme-değerlendirme araç-gereç ve yöntemlerine ilişkin bakış açılarına, kullanacakları araç-gereç ve yöntemleri neye göre belirlediklerine, bu konuda karşılaştıkları problemlerin neler olduğuna ve bu problemlerin çözümü için ne tür önlemler alınabileceğine ilişkin analiz sonuçları, ilgili konu içeriğini yansıtan kısa alt başlıklar halinde sunulmuştur.

\section{1. İlköğretim 6-8. sinıf öğretmenlerin ölçme-değerlendirme araç-gereç ve yöntemlerine ilişkin bakış açıları}

Tablo 2'de her bir ölçme-değerlendirme araç-gereç ve yöntemine ilişkin yer alan ifadelerin ortalamalarına genel olarak bakıldığında öğretmenlerin çoktan seçmeli test $(\bar{X}=2.51)$, gözlem $(\bar{X}=2.58)$, proje $(\bar{X}=2.76)$, kavram haritası $(\bar{X}=2.59)$, görüşme $(\bar{X}=2.62)$ ve rubrik (dereceli puanlama anahtarı) $(\bar{X}=2.73)$ yöntemlerinin hazırlanmasını zor; doğru-yanlış testi $(\bar{X}=2.85)$, boşluk doldurma testi $(\bar{X}=2.76)$, uzun cevaplı yazılı $(\bar{X}=2.56)$ ve sözlü sınavın $(\bar{X}=2.70)$ hazırlanmasını ise kolay buldukları görülmektedir. Öğretmenler, ölçme-değerlendirme araç-gereç ve yöntemlerinden uzun cevaplı yazılı $(\bar{X}=2.70)$, sözlü sinav $(\bar{X}=2.61)$, performans $(\bar{X}=2.53)$, proje $(\bar{X}=2.76)$, kavram haritas1 $(\bar{X}=2.59)$ ve drama $(\bar{X}=2.63)$ yöntemlerini kullanırken değerlendirme yapmanın zor olduğunu düşünürken, doğru-yanlış $(\bar{X}=2.84)$ ve kısa cevaplı testlerde $(\bar{X}=2.79)$ değerlendirmenin daha kolay olduğunu düşünmektedir. Öğretmenler çoktan seçmeli $(\bar{X}=2.71)$, doğru-yanlış $(\bar{X}=2.88)$ ve eşleştirme testlerinde $(\bar{X}=2.55)$ şans faktörünün etkili olduğunu belirtirken, sözlü sınavda $(\bar{X}=2.72)$ şansın etkili olmadı ̆̆ını belirtmişlerdir. Yine öğretmenler doğru-yanlış testi $(\bar{X}=2.84)$ ve rubrik (dereceli puanlama anahtarı) ( $\bar{X}=2.69)$ yöntemlerini objektiflik yönünden güvenilir bulurken, uzun cevaplı yazılı $(\bar{X}=2.64)$, sözlü sınav $(\bar{X}=2.83)$ ve grup/akran ve öz değerlendirme $(\bar{X}=2.82)$ yöntemlerini güvenilir bulmamaktadır. Ayrıca öğretmenlerin sözlü sınav $(\bar{X}=2.83)$, performans $(\bar{X}=2.84)$, proje $(\bar{X}=2.89)$, görüşme $(\bar{X}=2.83)$, gözlem $(\bar{X}=2.86)$, poster $(\bar{X}=2.77)$, rubrik (dereceli puanlama anahtarı) $(\bar{X}=2.76)$ ve drama $(\bar{X}=2.86)$ yöntemlerini zaman alıc1 görmekte olduğu, gözlem $(\bar{X}=2.72)$, kavram haritas1 $(\bar{X}=2.59)$, kontrol listeleri $(\bar{X}=2.64)$, görüşme $(\bar{X}=2.83)$, yapılandırılmış grid $(\bar{X}=2.51)$, rubrik (dereceli puanlama anahtarı) $(\bar{X}=2.73)$ ve grup/akran ve öz değerlendirme $(\bar{X}=2.74)$ yöntemlerinin de uzmanlaşma ve tecrübe gerektirdiğini vurguladıkları görülmektedir. Öğretmenler uzun cevaplı yazılı $(\bar{X}=2.68)$, sözlü sınav $(\bar{X}=2.51)$ ve projenin $(\bar{X}=2.74)$ üst düzey becerileri ölçtüğünü, çoktan seçmeli $(\bar{X}=2.64)$, boşluk doldurma $(\bar{X}=2.78)$ ve eşleştirme testlerinin $(\bar{X}=2.67)$ ise üst düzey becerileri ölçemediğini düşünmektedirler. Yine öğretmenlerin doğru-yanlış $(\bar{X}=2.53)$, boşluk doldurma $(\bar{X}=2.57)$ ve kısa cevaplı $(\bar{X}=2.60)$ testlerin her konu ve seviyeye uygun olduğunu, eşleştirme testi $(\bar{X}=2.68)$ ve projenin $(\bar{X}=2.59)$ ise uygun olmadığını düşündükleri görülmektedir. Ayrıca öğretmenler tarafindan, performans $(\bar{X}=2.72)$, proje $(\bar{X}=2.67)$, poster $(\bar{X}=2.75)$ ve drama $(\bar{X}=2.74)$ yöntemlerinin ek maliyet gerektirdiği, proje $(\bar{X}=2.65)$, kavram haritası $(\bar{X}=2.53)$ ve poster $(\bar{X}=2.54)$ gibi yöntemlerin ise öğrenciler açısından zor ve karmaşık olduğu düşünülmektedir. Son olarak öğretmenlerin, çoktan seçmeli testlerin $(\bar{X}=2.51)$ yorum yeteneğini körelttiğine, uzun cevaplı yazllıların $(\bar{X}=2.51)$ ise bu yeteneği arttırdığına inandıkları görülmektedir. Tüm bu bulgulara bakıldığında çalışmaya katılan öğretmenlerin daha çok alternatif ölçme-değerlendirme araç-gereç ve yöntemlerinin hazırlanması ve değerlendirilmesinin zor olduğunu, bu yöntemlerin zaman alıcı, uzmanlaşma ve tecrübe gerektirdiğini, ayrıca uygulanmasının ek maliyet gerektirdiği ve öğrenci tarafından genellikle zor ve karmaşık bulunduğunu belirttikleri görülmektedir.

Öğretmenlerin ölçme-değerlendirme araç-gereç ve yöntemlerine ilişkin Tablo 2'de yer alanlardan farklı olarak diğer seçeneği altında belirttikleri görüşlerden dikkat çekici olanların bazılarına değinmek gerekirse çoktan seçmeli test için "Kısmen güvenilirdir. Matematik dersi sinavlarında bu test 
sorularının çözümlerini de öğrencilerden isterseniz daha güvenilir ve faydall olur" ve "Yorum yeteneğini köreltir. Ancak içinde bulunduğumuz sistem bu yöntemin kullanımını gerektiriyor"; sözlü sınav için "Yönetmelikte yer almıyor. Bunun yerine ders ve etkinliklere katılım puanı veriyorum"; performans için "Araç-gereç sıkıntısı ve maliyet konuya göre değişir", "Ögrrencilerin ilgi ve isteklerine göre konu seçimi, doğru yönlendirme ve yönergeler ile eğlenceli hale getirilebilir" ve "Faydalı bir yöntem değildir"; proje için "Öğrenciyi günün şartlarına ve hayata hazırlamadı̆̆ için ögretime bir katkısı yoktur"; kontrol listeleri için "Uygulanması gerekir. Ancak kazanım ve konular arasında ilişki kurmak yetenek ve uzmanlık gerektirir'; görüşme için "Öğrenci ve konuya göre değişiklik gösterir. Karşıllkl etkileşim, süreci ve sonucu etkiler"; poster için "Her konuya uygun değill"; grup/akran ve öz değerlendirme için de "Güvenilirliği düşüktür. Yanlı sonuçlar çıkabilir", şeklinde görüş bildirmişlerdir. 
Tablo 2. Öğretmenlerin Ölçme-Değerlendirme Araç-Gereç ve Yöntemlerine İlişkin Görüşleri

\begin{tabular}{|c|c|c|c|c|c|c|c|c|c|c|}
\hline & & & \multicolumn{2}{|c|}{ Katılıyorum } & \multicolumn{2}{|c|}{ Katılmiyorum } & \multicolumn{2}{|c|}{$\begin{array}{c}\text { Fikrim } \\
\text { Yok }\end{array}$} & \multicolumn{2}{|c|}{ Ortalama } \\
\hline & & & f & $\%$ & f & $\%$ & f & $\%$ & $\boldsymbol{\Sigma} \mathbf{f}$ & $\bar{X}$ \\
\hline \multirow{6}{*}{ ن } & \multirow{6}{*}{ 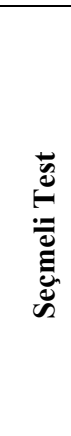 } & Tanımayı ölçen basit bir ölçmedir. & 302 & 63.7 & 138 & 29.1 & 12 & 2.5 & 452 & 2.64 \\
\hline & & Yüzeysel ölçme yapar. & 240 & 50.6 & 204 & 43 & 6 & 1.3 & 450 & 2.52 \\
\hline & & Hazırlaması zordur. & 236 & 49.8 & 212 & 44.7 & 4 & 0.8 & 452 & 2.51 \\
\hline & & Güvenilirdir. & 228 & 48.1 & 195 & 41.1 & 25 & 5.3 & 448 & 2.45 \\
\hline & & Şans faktörü etkilidir. & 334 & 70.5 & 114 & 24.1 & 9 & 1.9 & 457 & 2.71 \\
\hline & & Yorum yeteneğini köreltir. & 277 & 58.4 & 161 & 34 & 12 & 2.5 & 450 & 2.59 \\
\hline \multirow{7}{*}{ 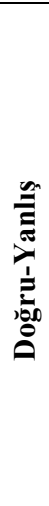 } & \multirow{7}{*}{ 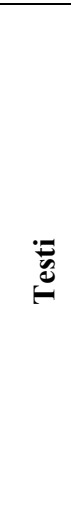 } & Şans faktörü etkilidir. & 404 & 85.2 & 53 & 11.2 & 2 & 0.4 & 459 & 2.88 \\
\hline & & Önemsiz ve ezbere dayalı bilgiyi ölçer. & 187 & 39.5 & 263 & 55.5 & 6 & 1.3 & 456 & 2.40 \\
\hline & & Öğrenme yanlışlıklarını ortaya çıkarmaz. & 236 & 49.8 & 210 & 44.3 & 9 & 1.9 & 455 & 2.50 \\
\hline & & Ayırt ediciliği düşüktür. & 327 & 69 & 123 & 25.9 & 7 & 1.5 & 457 & 2.70 \\
\hline & & Puanlaması kolay ve objektiftir. & 386 & 81.4 & 71 & 15 & 1 & 0.2 & 458 & 2.84 \\
\hline & & Hazırlaması kolaydır. & 394 & 83.1 & 57 & 12 & 5 & 1.1 & 456 & 2.85 \\
\hline & & Her konuya uygundur. & 251 & 53 & 193 & 40.7 & 11 & 2.3 & 455 & 2.53 \\
\hline \multirow{5}{*}{\multicolumn{2}{|c|}{ 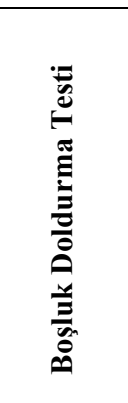 }} & $\begin{array}{l}\text { Bilgiyi hatırlamanın ölçüldüğü basit bir } \\
\text { ölçmedir. }\end{array}$ & 365 & 77 & 97 & 20.5 & 3 & 0.6 & 465 & 2.78 \\
\hline & & Hazırlaması kolaydır. & 353 & 74.5 & 104 & 21.9 & 3 & 0.6 & 460 & 2.76 \\
\hline & & İstenilenin dışındaki yanıtlar da doğru olabilir. & 262 & 55.3 & 180 & 38 & 15 & 3.2 & 457 & 2.54 \\
\hline & & Puanlaması zordur. & 108 & 22.8 & 341 & 71.9 & 6 & 1.3 & 455 & 2.22 \\
\hline & & Her seviyeye uygundur. & 273 & 57.6 & 174 & 36.7 & 12 & 2.5 & 459 & 2.57 \\
\hline \multirow{5}{*}{\multicolumn{2}{|c|}{ 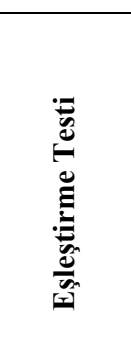 }} & Her konu için ilişki oluşturmak zordur. & 322 & 67.9 & 127 & 26.8 & 9 & 1.9 & 458 & 2.68 \\
\hline & & Üst düzey davranışları ölçemez. & 313 & 66 & 130 & 27.4 & 11 & 2.3 & 454 & 2.67 \\
\hline & & Ezbere yöneltir. & 218 & 46 & 226 & 47.7 & 12 & 2.5 & 456 & 2.45 \\
\hline & & Hazırlaması zordur. & 151 & 31.9 & 292 & 61.6 & 13 & 2.7 & 456 & 2.30 \\
\hline & & Şans faktörü etkilidir. & 265 & 55.9 & 175 & 36.9 & 15 & 3.2 & 455 & 2.55 \\
\hline
\end{tabular}


Tablo 2. (Devamı)

\begin{tabular}{|c|c|c|c|c|c|c|c|c|c|}
\hline & & \multicolumn{2}{|c|}{ Katılıyorum } & \multicolumn{2}{|c|}{ Katılmıyorum } & \multicolumn{2}{|c|}{ Fikrim Yok } & \multicolumn{2}{|c|}{ Ortalama } \\
\hline & & f & $\%$ & $\mathbf{f}$ & $\%$ & f & $\%$ & $\Sigma \mathbf{f}$ & $\bar{X}$ \\
\hline \multirow{4}{*}{ 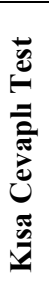 } & Öğrenciyi ezbere teşvik eder. & 253 & 53.4 & 195 & 41.1 & 10 & 2.1 & 458 & 2.53 \\
\hline & Hazırlaması zordur. & 114 & 24.1 & 329 & 69.4 & 9 & 1.9 & 452 & 2.23 \\
\hline & Puanlaması kolaydır. & 370 & 78.1 & 77 & 16.2 & 9 & 1.9 & 456 & 2.79 \\
\hline & Her seviyeye uygundur. & 294 & 62 & 145 & 30.6 & 18 & 3.8 & 457 & 2.60 \\
\hline \multirow{7}{*}{ 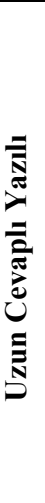 } & Puanlama güvenirliği zayıftır. & 302 & 63.7 & 145 & 30.6 & 9 & 1.9 & 456 & 2.64 \\
\hline & Hazırlaması kolaydır. & 260 & 54.9 & 196 & 41.4 & 3 & 0.6 & 459 & 2.56 \\
\hline & Puanlaması zordur. & 324 & 68.4 & 132 & 27.8 & 2 & 0.4 & 458 & 2.70 \\
\hline & Kapsam geçerliği düşüktür. & 171 & 36.1 & 267 & 56.3 & 14 & 3 & 452 & 2.35 \\
\hline & Üst düzey davranışları ölçer. & 321 & 67.7 & 119 & 25.1 & 14 & 3 & 454 & 2.68 \\
\hline & Ölçmeye başka değişkenler karışabilir. & 345 & 72.8 & 95 & 20 & 15 & 3.2 & 455 & 2.73 \\
\hline & Öğrencilerde yorum yeteneğini arttırır. & 410 & 86.5 & 43 & 9.1 & 5 & 1.1 & 458 & 2.88 \\
\hline \multirow{5}{*}{ 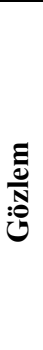 } & Hazırlamas1 zordur. & 284 & 59.9 & 146 & 30.8 & 21 & 4.4 & 451 & 2.58 \\
\hline & Uzmanlaşma gerektirir. & 351 & 74.1 & 90 & 19 & 19 & 4 & 460 & 2.72 \\
\hline & Her konuya uygundur. & 173 & 36.5 & 247 & 52.1 & 39 & 8.2 & 459 & 2.29 \\
\hline & Objektif değildir. & 226 & 47.7 & 196 & 41.4 & 36 & 7.6 & 458 & 2.41 \\
\hline & Tüm öğrencilerin gözlenmesi zaman alır. & 401 & 84.6 & 42 & 8.9 & 11 & 2.3 & 454 & 2.86 \\
\hline \multirow{10}{*}{$\begin{array}{l}\text { 离 } \\
\text { ज्ञ } \\
\text { : }\end{array}$} & Uygulanması zaman alır. & 388 & 81.9 & 70 & 14.8 & 5 & 1.1 & 463 & 2.83 \\
\hline & Ölçmeye başka değişkenler karışabilir. & 391 & 82.5 & 60 & 12.7 & 8 & 1.7 & 459 & 2.83 \\
\hline & Öğrenciler arasında adaletsizliğe neden olur. & 292 & 61.6 & 157 & 33.1 & 9 & 1.9 & 458 & 2.62 \\
\hline & Sözel iletişimi geliştirir. & 409 & 86.3 & 45 & 9.5 & 7 & 1.5 & 461 & 2.87 \\
\hline & Üst düzey davranışları ölçer. & 245 & 51.7 & 202 & 42.6 & 12 & 2.5 & 459 & 2.51 \\
\hline & Hazırlaması kolaydır. & 325 & 68.6 & 129 & 27.2 & 5 & 1.1 & 459 & 2.70 \\
\hline & Geçerlik ve güvenirlik düşüktür. & 268 & 56.5 & 181 & 38.2 & 12 & 2.5 & 461 & 2.56 \\
\hline & Puanlaması zordur. & 287 & 60.5 & 160 & 33.8 & 10 & 2.1 & 457 & 2.61 \\
\hline & Şans başarısı yoktur. & 337 & 71.1 & 112 & 23.6 & 9 & 1.9 & 458 & 2.72 \\
\hline & Objektif değildir. & 269 & 56.8 & 174 & 36.7 & 15 & 3.2 & 458 & 2.55 \\
\hline
\end{tabular}


Tablo 2. (Devami)

\begin{tabular}{|c|c|c|c|c|c|c|c|c|c|}
\hline & & \multicolumn{2}{|c|}{ Katılıyorum } & \multicolumn{2}{|c|}{ Katılmıyorum } & \multicolumn{2}{|c|}{ Fikrim Yok } & \multicolumn{2}{|c|}{ Ortalama } \\
\hline & & f & $\%$ & $\mathbf{f}$ & $\%$ & $\mathbf{f}$ & $\%$ & $\Sigma \mathbf{f}$ & $\overline{\mathrm{X}}$ \\
\hline \multirow{6}{*}{ 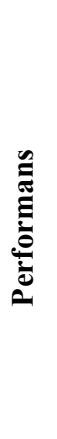 } & Zaman alır. & 396 & 83.5 & 64 & 13.5 & 6 & 1.3 & 466 & 2.84 \\
\hline & Öğrenci için zor ve korkutucudur. & 212 & 44.7 & 245 & 51.7 & 5 & 1.1 & 462 & 2.45 \\
\hline & Puanlaması zordur. & 249 & 52.5 & 209 & 44.1 & 5 & 1.1 & 463 & 2.53 \\
\hline & Öğrenci için sıkıcıdır. & 247 & 52.1 & 207 & 43.7 & 8 & 1.7 & 462 & 2.52 \\
\hline & Öğrenci yerine veliler yapar. & 343 & 72.4 & 97 & 20.5 & 26 & 5.5 & 466 & 2.68 \\
\hline & Araç-gereç sıkıntısı ve maliyete yol açar. & 338 & 71.3 & 115 & 24.3 & 8 & 1.7 & 461 & 2.72 \\
\hline \multirow{8}{*}{$\stackrel{0}{\stackrel{0}{0}}$} & Üst düzey davranışları ölçer. & 349 & 73.6 & 111 & 23.4 & 5 & 1.1 & 465 & 2.74 \\
\hline & Zaman alır. & 416 & 87.8 & 47 & 9.9 & 2 & 0.4 & 465 & 2.89 \\
\hline & Öğrenci düzeyine uygun konu bulmak zordur. & 276 & 58.2 & 185 & 39 & 3 & 0.6 & 464 & 2.59 \\
\hline & Hazırlaması ve değerlendirmesi zordur. & 353 & 74.5 & 104 & 21.9 & 4 & 0.8 & 461 & 2.76 \\
\hline & Objektif değildir. & 183 & 38.6 & 264 & 55.7 & 12 & 2.5 & 459 & 2.37 \\
\hline & Öğrenci için külfetlidir. & 311 & 65.6 & 143 & 30.2 & 10 & 2.1 & 464 & 2.65 \\
\hline & Ek maliyet gerektirir. & 324 & 68.4 & 130 & 27.4 & 11 & 2.3 & 465 & 2.67 \\
\hline & Öğrenciden ziyade veli ön plandadır. & 306 & 64.6 & 136 & 28.7 & 25 & 5.3 & 467 & 2.60 \\
\hline \multirow{9}{*}{ 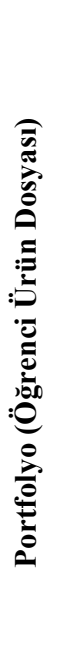 } & İçeriğe karar vermek zordur. & 276 & 58.2 & 162 & 34.2 & 22 & 4.6 & 460 & 2.55 \\
\hline & Objektif değildir. & 204 & 43 & 235 & 49.6 & 21 & 4.4 & 460 & 2.40 \\
\hline & Öğrenci becerilerini geliştirir. & 357 & 75.3 & 87 & 18.4 & 20 & 4.2 & 464 & 2.73 \\
\hline & Hem ürünü hem de süreci değerlendirir. & 373 & 78.7 & 72 & 15.2 & 16 & 3.4 & 461 & 2.77 \\
\hline & Güvenirliği düşüktür. & 184 & 38.8 & 252 & 53.2 & 24 & 5.1 & 460 & 2.35 \\
\hline & Öğrenci gelişimi hakkında bilgi verir. & 345 & 72.8 & 95 & 20 & 19 & 4 & 459 & 2.71 \\
\hline & Üretilen ürünleri öğrencinin yaptığı kestirilemez. & 279 & 58.9 & 158 & 33.3 & 23 & 4.9 & 460 & 2.56 \\
\hline & Saklama konusunda yer sıkıntısı olabilir. & 339 & 71.5 & 104 & 21.9 & 16 & 3.4 & 459 & 2.70 \\
\hline & Planlama ve zamanlama problemi vardır. & 337 & 71.1 & 98 & 20.7 & 23 & 4.9 & 458 & 2.69 \\
\hline
\end{tabular}


Tablo 2. (Devamı)

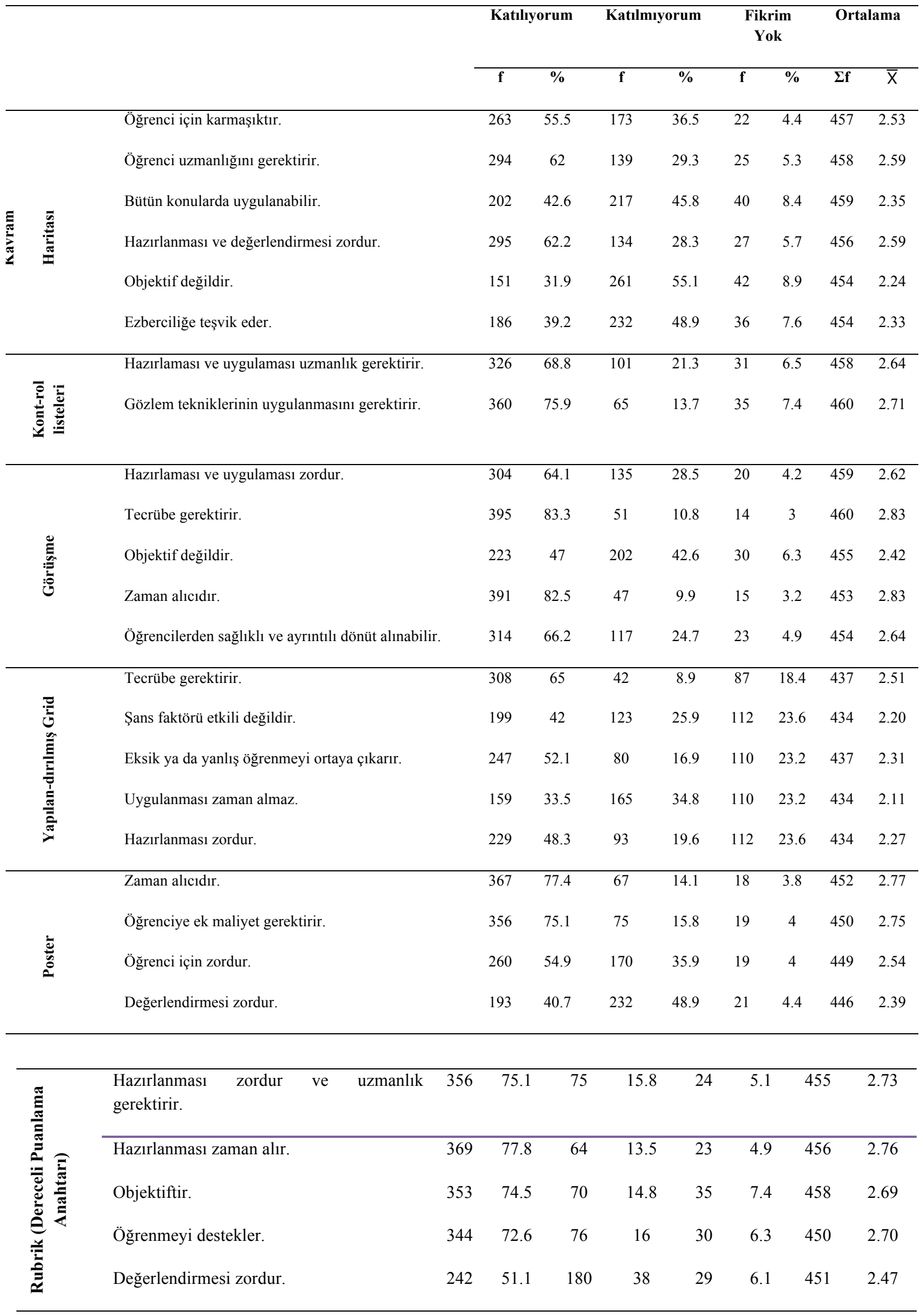




\begin{tabular}{|c|c|c|c|c|c|c|c|c|c|}
\hline & İyi bir hazırlık ve plan gerektirir. & 427 & 90.1 & 20 & 4.2 & 16 & 3.4 & 463 & 2.89 \\
\hline \multirow{5}{*}{ 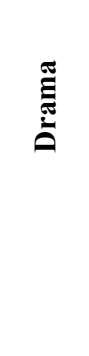 } & Uygulaması zaman alıcıdır. & 408 & 86.1 & 36 & 7.6 & 15 & 3.2 & 459 & 2.86 \\
\hline & Materyaller için ek maliyet gerektirir. & 353 & 74.5 & 82 & 17.3 & 17 & 3.6 & 452 & 2.74 \\
\hline & Değerlendirmesi zordur. & 303 & 63.9 & 127 & 26.8 & 21 & 4.4 & 451 & 2.63 \\
\hline & Sınıfı derse odaklamak zordur. & 261 & 55.1 & 173 & 36.5 & 20 & 4.2 & 454 & 2.53 \\
\hline & Ders asıl amacindan sapabilir. & 299 & 63.1 & 130 & 27.4 & 26 & 5.5 & 455 & 2.60 \\
\hline \multirow{7}{*}{ 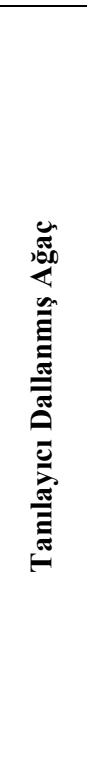 } & Yanlış anlamaları ortaya çıkarır. & 252 & 53.2 & 89 & 18.8 & 101 & 21. & 442 & 2.34 \\
\hline & Hazırlaması zaman alıcıdır. & 301 & 63.5 & 52 & 11 & 92 & $\begin{array}{c}19 . \\
4\end{array}$ & 445 & 2.47 \\
\hline & Tecrübe gerektirir. & 297 & 62.7 & 52 & 11 & 95 & 20 & 444 & 2.45 \\
\hline & Şans faktörü etkili olabilir. & 156 & 32.9 & 174 & 36.7 & 110 & $\begin{array}{c}23 . \\
2\end{array}$ & 440 & 2.10 \\
\hline & Üst düzey becerileri ölçemez. & 185 & 39 & 142 & 30 & 114 & $\begin{array}{c}24 . \\
1\end{array}$ & 441 & 2.16 \\
\hline & Öğrenci için karmaşıktır. & 222 & 46.8 & 123 & 25.9 & 98 & $\begin{array}{c}20 . \\
7\end{array}$ & 443 & 2.28 \\
\hline & Değerlendirmesi zordur. & 208 & 43.9 & 132 & 27.8 & 102 & $\begin{array}{c}21 . \\
5\end{array}$ & 442 & 2.24 \\
\hline \multirow{4}{*}{ 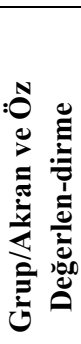 } & $\begin{array}{l}\text { Öğrencilerin yanlı davranma } \text { olasıllı̆ } 1 \\
\text { vardır. }\end{array}$ & 394 & 83.1 & 45 & 9.5 & 19 & 4 & 458 & 2.82 \\
\hline & Değerlendirmesi zordur. & 322 & 67.9 & 107 & 22.6 & 24 & 5.1 & 442 & 2.24 \\
\hline & Öğrenci tecrübesi ve deneyimi gerektirir. & 360 & 75.9 & 71 & 15 & 23 & 4.9 & 454 & 2.74 \\
\hline & Öğrenciler yeteneklerini kendileri keşfeder. & 346 & 73 & 89 & 18.8 & 21 & 4.4 & 456 & 2.71 \\
\hline
\end{tabular}

3.2. İlköğretim 6-8. slnıf öğretmenlerin kullanacakları ölçme-değerlendirme araç-gereç ve yöntemlerini belirleme kriterleri

Tablo 3. Öğretmenlerin Kullanılan Ölçme-Değerlendirme Araç-Gereç ve Yöntemleri Belirleme Kriterlerine Göre Dağ 11 lım

\begin{tabular}{lcc}
\hline Araç-Gereç ve Yöntemleri Belirleme Kriteri & f & \% \\
\hline Öğrencinin akademik başarısı & 266 & 56.1 \\
Sınıf mevcudu & 226 & 47.7 \\
Kendi yeterliklerim & 173 & 36.5 \\
Sıııf ve okulun mevcut imkânları & 332 & 70.0 \\
Öğrenci seviyesi & 412 & 86.9 \\
Zaman & 270 & 57.0 \\
İdareci ve velilerin tercihleri & 34 & 7.2 \\
İşlenen konu & 384 & 81.0 \\
\hline
\end{tabular}


Tablo 3 incelendiğinde çalışmaya katılan öğretmenlerin büyük çoğunluğu herhangi bir ölçmedeğerlendirme araç-gereç ve yöntemi kullanmadan önce en fazla öğrenci seviyesini (\%86.9) ve işlenen konuyu (\%81), en az ise idareci ve velilerin tercihlerini (\%7.2) göz önünde bulundurdukları görülmektedir.

Tablo 4'de öğretmenlerin kullanacakları ölçme-değerlendirme araç-gereç ve yöntemleri belirleme kriterlerine ilişskin diğer düşünceleri yer almaktadır.

Tablo 4. Öğretmenlerin Kullanacakları Ölçme-Değerlendirme Araç-Gereç ve Yöntemleri Belirleme Kriterlerine İlişkin Diğer Düşünceleri

\begin{tabular}{lc}
\hline Araç-Gereç ve Yöntemleri Belirleme Kriteri & f \\
\hline Ülke genelinde yapılan sınavlara uygun olarak daha çok çoktan seçmeli testi kullanıyorum & 2 \\
Maddi imkânlar & 1 \\
Yönetmeliğe göre kullanılması zorunlu olan yöntemleri kullanıyorum & 2 \\
\hline
\end{tabular}

\section{3. İlköğretim 6-8. sınıf öğretmenlerinin ölçme-değerlendirme araç-gereç ve yöntemlerini kullanırken karşılaştıkları problemler}

Tablo 5. Öğretmenlerin Ölçme-Değerlendirme Araç-Gereç ve Yöntemleri Kullanılırken Karşılaştıkları Problemler

\begin{tabular}{lcc}
\hline Karşılaşılan Problemler & f & \% \\
\hline Yeterli bilgi ve beceriye sahip değilim & 27 & 5.7 \\
Yükseköğretimde bu yöntemler hakkında yeterli bilgi verilmedi & 179 & 37.8 \\
Zaman alıcı olarak görüyorum & 137 & 28.9 \\
Yapılandırmacı yaklaşımın egemen olduğu yeni öğretim programına yabancıyım & 41 \\
Mevcut altyapapı (araç-gereç eksikliği, sınıfların kalabalık oluşu vb.) & 8.6 \\
Öğretmen, öğrenci ve velinin ölçme değerlendirme ile ilgili sahip olduğu kültürün değiştirilmesi çok güç & 214 \\
Ölçme değerlendirme ile ilgili formlar karmaş1k ve sayıca fazla & 45.0 \\
Ülke genelinde uygulanan sınavlar (SBS, YGS, vb.) bu yöntemlerin uygulanmasını engelliyor & 205 \\
Öğgrenci seviyesi (bilgi, gelişim düzeyi, hayal gücü vb.) düşük & 43.2 \\
Yöntemler karmaşı ve uygulamak çok zor & 280 \\
Yöntemlerin hazırlanması güç & 291 \\
Aileler bu konuda bilinçsiz & 97.1 \\
Kriter belirleme ve ölçek hazırlama uğraştırıcı & 20.5 \\
Özellikle dershaneye giden öğrenciler performans, proje gibi ödevleri zaman kaybı görüyor & 154 \\
Fazla zaman, fazla materyal ve fazla uğraş gerektirir & 292.5 \\
Verilen hizmet içi eğitimler yetersiz & 61.6 \\
\hline
\end{tabular}

Tablo 5 incelendiğinde öğretmenlerin ölçme-değerlendirme araç-gereç ve yöntemlerini kullanırken en sık karşılaştıkları problemlerin başında mevcut altyapı eksikliği (araç-gereç eksikliği, sınıfların kalabalık oluşu vb.) (\%65), özellikle dershaneye giden öğrencilerin performans, proje gibi ödevleri zaman kaybı görmesi (\%63.3), ailelerin bu konuda bilinçsiz olması (\%61.6) ve öğrenci seviyesinin (bilgi, gelişim düzeyi, hayal gücü vb.) düşüklüğü (61.4) gibi problemler gelmektedir. Öğretmenlerin bu konuda en az yaşadıkları problemler ise bilgi ve beceri eksikliği (\%5.7) ve yapılandırmacı yaklaşımın egemen olduğu yeni öğretim programına yabancı olmalarıdır (\%8.6). Bu bulgulardan yola çıkılarak ölçme-değerlendirme alanındaki sorunların öğretmen kaynaklı olmadığı genellikle öğrenci ve velilerin bu konuda bilgisiz ve isteksiz olmaları, ayrıca mevcut altyapıdan kaynaklanan bir takım eksikliklerin bulunduğu söylenebilir. Ayrıca tablo 6'da öğretmenlerin ölçme-değerlendirme araç-gereç ve yöntemleri kullanılırken tablo 5'de yer verilenlerden farklı olarak karşılaştıkları diğer problemler gösterilmiştir. 
Tablo 6. Öğretmenlerin Ölçme-Değerlendirme Araç-Gereç ve Yöntemleri Kullanılırken Karşılaştıkları Diğer Problemler

\begin{tabular}{lc}
\hline Karşılaşılan Problemler & f \\
\hline Ailelerin kültürü, eğitim düzeyi ve ekonomik düzeyinin öğrenci ödevlerine etkisi çoktur. Öğrenciler eşit şartlarda & 1 \\
değiller & \\
Müfredat çok yoğun, ölçme-değerlendirme yöntemlerini uygulamak zaman alıyor & 4 \\
Öğretmenlerin iş yükü fazla (e-okul, anketler, not girişleri, yazıllılar vs.) & 4 \\
\hline
\end{tabular}

\section{4. İlköğretim 6-8. sinıf ögretmenlerinin ölçme-değerlendirme araç-gereç ve yöntemlerine ilişkin yaklaşımlarını geliştirmek için alınabilecek önlemler}

Tablo 7. Öğretmenlerin Ölçme-Değerlendirme Araç-Gereç ve Yöntemlerine ilişkin Yaklaşımlarını Geliştirmek ve Karşılaşılan Problemleri Giderebilmek İçin Belirttikleri Öneriler

\begin{tabular}{lcc}
\hline Çözüme Yönelik Öneriler & f & $\mathbf{\%}$ \\
\hline Hizmet içi eğitim verilmeli & 94 & 19.8 \\
Eğitim fakültelerindeki eğitim programlarında bu alana yönelik derslere ağırlık verilmeli & 182 & 38.4 \\
İlgili yönteme uygun ölçekler geliştirilip öğretmenlerin kullanımına sunulmalı & 167 & 35.2 \\
Öğretmenlerin bulundukları bölge ya da okulda ölçme-değerlendirme uzmanı bulundurulmalı & 144 & 30.4 \\
Verilen hizmet içi eğitimlerin kalitesi arttırılıp, eğitimde uygulamaya daha çok ağırlık verilmeli & 176 & 37.1 \\
\hline
\end{tabular}

Tablo 7 incelendiğinde araştırmaya katılan öğretmenlerin ölçme-değerlendirme araç-gereç ve yöntemleri alanında yaşanan sorunların giderilebilmesi ve yaklaşımların geliştirilebilmesi açısından en çok üzerinde durdukları nokta eğitim fakültelerindeki eğitim programlarında bu alana yönelik derslere ağırlık verilmesi gerektiği (\%38.4) olmuştur. Bunun yanında bu alanda en az kabul gören görüş ise hizmet içi eğitim verilmesi gerektiğidir (\%19.8). Ancak verilen hizmet içi eğitimlerin kalitesi arttırılıp, eğitimde uygulamaya daha çok ağılık verilmeli (\%37.1) görüşünün ağıllıklı olarak kabul edilmesi karşısında ölçme-değerlendirme alanında hizmet içi eğitim verilmesi konusunda herhangi bir sorun yaşanmadığ

Tablo 8'de öğretmenlerin ölçme-değerlendirme araç-gereç ve yöntemlerine ilişkin yaklaşımlarını geliştirmek ve karşılaşılan problemleri giderebilmek için yukarıdakilerden farklı olarak belirttikleri diğer önerilere yer verilmiştir.

Tablo 8. Öğretmenlerin Ölçme-Değerlendirme Araç-Gereç ve Yöntemlerine ilişkin Yaklaşımlarını Geliştirmek ve Karşılaşılan Problemleri Giderebilmek İçin Belirttikleri Diğer Öneriler

\begin{tabular}{|c|c|}
\hline Çözüme Yönelik Öneriler & $\mathbf{f}$ \\
\hline Akademik çalışmaların sahaya aktarılması ve gerçek yaşamla ilişkilendirilmesi gerekmektedir & 1 \\
\hline $\begin{array}{l}\text { Okulların alt yapı eksiklikleri giderilmeli, öğrenci ve velilere ölçme-değerlendirme yöntemleri hakkında bilgi } \\
\text { verilmeli }\end{array}$ & 7 \\
\hline Eğitim fakültelerinde çeşitli ölçekler uygulamalı olarak kullandırılmalı & 1 \\
\hline $\begin{array}{l}\text { Her öğretmenden dersine ve branşına göre örnek ölçekler yapmaları ve bu ölçekleri uygulama sürecine } \\
\text { uyarlamaları istenebilir. Ayrıca öğretmenden bu yapıtını tez gibi savunması istenebilir }\end{array}$ & 1 \\
\hline Kitaplardaki konular ölçme-değerlendirme yöntemlerine uygun hale getirilmeli & 1 \\
\hline Müfredatta ölçme-değerlendirme uygulamalarını yapacak gerekli zaman verilmeli & 1 \\
\hline Öğretmenin iş yükü azaltılmalı. Sürekli eksik bir evrağım var mı diye korku ve kaygı içindeyim & 2 \\
\hline Özellikle öğretmenlik mesleği saygınlaştırılmalı, öğretmene mesleği sevdirilerek motive edilmeli & 2 \\
\hline Yurt genelinde uygulanan sınavlarda da çok çeşitli yöntem ve tekniklerin kullanılması gerekli & 1 \\
\hline Ölçme-değerlendirme yöntem ve tekniklerinden en etkili olanları seçilip uygulanması sağlanmalı. & 1 \\
\hline Uygulanabilirlik ve çevre şartları göz önünde bulundurulmalı & 1 \\
\hline
\end{tabular}

Kâğıt israfını önlemek ve daha pratik olması açısından tüm dokümanların bilgisayar ortamında işlenip saklanması gerekli

Uzman kişiler tarafından hazırlanan, uygulaması kolay olan yöntemler teknoloji eşliğinde uygulanmalı 


\section{Sonuç, Tartışma ve Öneriler}

Anketten elde edilen bulgular 1şığında öğretmenlerin çoktan seçmeli test, gözlem, proje, kavram haritası, görüşme ve rubrik (dereceli puanlama anahtarı) yöntemlerinin hazırlanmasını zor; doğruyanlış testi, boşluk doldurma testi, uzun cevaplı yazılı ve sözlü sınavın hazırlanmasını ise kolay buldukları görülmektedir. Öğretmenler, ölçme-değerlendirme araç-gereç ve yöntemlerinden uzun cevaplı yazılı, sözlü sınav, performans, proje, kavram haritası ve drama yöntemlerini kullanırken değerlendirme yapmanın zor olduğunu düşünürken, doğru-yanlış ve kısa cevaplı testlerde değerlendirmenin daha kolay olduğunu düşünmektedir. Ayrıca öğretmenlerin sözlü sınav, performans, proje, görüşme, gözlem, poster, rubrik (dereceli puanlama anahtarı) ve drama yöntemlerini zaman alıcı görmekte olduğu, gözlem, kavram haritası, kontrol listeleri, görüşme, yapılandırılmış grid, rubrik (dereceli puanlama anahtarı) ve grup/akran ve öz değerlendirme yöntemlerinin de uzmanlaşma ve tecrübe gerektirdiğini vurguladıkları görülmektedir. Tüm bunlara ek olarak öğretmenler; performans, proje, poster ve drama yöntemlerinin ek maliyet gerektirdiğini; proje, kavram haritası ve poster gibi yöntemlerin de öğrencilere zor ve karmaşık geldiğini düşünmektedirler. Bu bulgulara göre çalışmaya katılan öğretmenlerin genellikle alternatif ölçme-değerlendirme araç-gereç ve yöntemlerinin hazırlanmasının ve değerlendirilmesinin zor olduğunu, bu yöntemlerin zaman alıcı, uzmanlaşma ve tecrübe gerektirdiğini, ayrıca uygulanmasının ek maliyet gerektirdiği ve öğrenci tarafından genellikle zor ve karmaşık bulunduğunu belirttikleri görülmektedir. Alternatif ölçme-değerlendirme araç-gereç ve yöntemleri hakkındaki bu olumsuz görüșlerin altında, öğretmenler tarafından bu yöntemlerin tüm yönleriyle çok fazla bilinmemesi ve kendilerinde bu yöntemleri uygulayabilecek cesareti bulamamaları, ayrıca mevcut imkânların yöntemleri uygulamada engel oluşturması gibi sebeplerin yattığı söylenebilir. Buna paralel olarak, öğretmenler ölçme-değerlendirme araç-gereç ve yöntemleri hakkında daha fazla bilgi ve cesaret kazandıracak çeşitli yaşantılar içine sokularak ve olumsuz yaklaşımları engellemek için mevcut imkânları iyileştirerek bu tür sorunların üstesinden gelinebileceğine inanılmaktadır. Bu konuda yapılan çeşitli araştırmalara bakıldığında araştırma bulgularıyla paralel olarak öğretmenlerin alternatif yöntemlere ilişkin olumlu görüş bildirdikleri, bu yöntemlerin yararlarına ve eğitim-öğretim sürecine katkı sağlayacağına inandıkları, ancak bu yöntemlerin uygulanmasının zor olması ve çok zaman alması ayrıca öğrenci seviyesine uygun olmaması gibi nedenler öne sürerek olumsuz yaklaştıkları da ortaya çıkarılmıştır (Duban ve Küçükyılmaz, 2008; Gömleksiz vd., 2011; Metin ve Demiryürek, 2009; Sağlam Arslan vd., 2009; Şaşmaz Ören ve Tatar, 2007; Yıldırım ve Karakoç Öztürk, 2009). Esen ve Güneş (2012) tarafından yapılan araştırmada öğretmenlerin amacına uygun olarak hazırlandığında proje ve performans ödevlerini yararlı buldukları, proje ve performans verme amaçlarının öğrencinin araştırma becerisini geliştirmek olduğu ve bu amacın yenilenen öğretim programının amaçları ile örtüştüğü görülmüştür. Yine Duran, Mıhladız ve Ballıel (2013) yaptıkları araştırmada, öğretmenlerin alternatif değerlendirme yöntemlerine yönelik tutumlarının olumlu olduğu ve bu yöntemleri çoğunlukla gerekli bulduklarını ortaya çıkarmışlardır. Bu sonuç Şahin ve Abalı Öztürk (2014) tarafından sınıf öğretmeni adayları ile yapılan araştırma bulgularıyla da örtüşmektedir. Akbaş ve Gençtürk (2013) tarafından yapılan araştırmada ise öğretmenler alternatif yöntemleri uygulanabilir olarak görmüş ve öğrencilerin öz değerlendirmelerine katkı sağladığını belirtmişlerdir. Ancak bu yöntemlerin hazırlama, uygulama ve nota dönüştürme sürecinin zaman aldığı, öğretmen ve öğrenciye ilave yük getirdiği, puanlama ve değerlendirmesinin zor olduğunu da ifade etmişlerdir.

Araştırma sonucunda elde edilen bulgulara bakıldığında öğretmenlerin büyük çoğunluğunun herhangi bir ölçme-değerlendirme araç-gereç ve yöntemi kullanmadan önce en fazla sırasıyla öğrenci seviyesini, işlenen konuyu, sınıf ve okulun mevcut imkânlarını, zamanı ve öğrencinin akademik başarısını, en az da idareci ve velilerin tercihlerini dikkate aldıkları görülmektedir. Bu duruma bakılarak ölçme ve değerlendirme konusunda idareci ve velilerin öğretmenler üzerinde çok az bir etkisinin olduğu, eğer herhangi bir yöntemin daha sağlıklı bir şekilde uygulanması isteniyorsa öğrenci seviyelerinin ve işlenen konunun bu yöntemi uygulamaya uygun hale getirilmesi gerektiği söylenebilir. Bunun için öğrencilerin ölçme-değerlendirme araç-gereç ve yöntemleri hakkında bilgilendirilmesi ve kendisinden istenenin ne olduğu, bunu nasıl yapması gerektiği, hangi kriterlere göre ne şekilde değerlendirileceği öğrenciye tam olarak açıkça bildirilmelidir. Ayrıca öğretmenlerin konuya uygun ölçme-değerlendirme araç-gereç ve yöntemlerini kullanması daha sağlılı bir ölçme- 
değerlendirme için gerekli görülmektedir. Bu konuda yapılan çeşitli araştırmalarda öğretmenlerin kullanacakları ölçme-değerlendirme araç-gereç ve yöntemleri belirlerken kendi yeterliklerini (Gelbal ve Kelecioğlu, 2007), sahip oldukları bilgi düzeylerini (Nazlıçiçek ve Akarsu, 2008) ve alışkanlıklarını (Birgin ve Gürbüz, 2008) dikkate aldıkları ortaya çıkarılmıştır. Ayrıca Yıldırım ve Semerci (2006) tarafından yapılan araştırmada öğretmenlerin sınav türünü belirlerken kendi branşlarındaki diğer öğretmenlere danışmakta olduğunu ve sorularını bilişsel alanın kavrama basamağına uygun olarak hazırladıkları görülmüştür. Yine Şaşmaz Ören ve Tatar'ın (2007) tarafından yapılan araştırmada ögretmenlerin derslerde alternatif değerlendirme tekniklerini tercih etmelerinde uygulamaya yönelik üniteler, konunun grup çalışmasına uygun olup olmadığı ve konu ile ilgili örnek materyallerin bolluğu gibi faktörleri dikkate aldıkları ortaya çıkarılmıştır.

Anketten elde edilen bulgulara göre araştırmaya katılan öğretmenlerin yarıdan fazlasının ölçmedeğerlendirme araç-gereç ve yöntemlerini kullanırken mevcut altyapının (araç-gereç sıkıntısı, sınıfların kalabalık oluşu vb.) eksik olması, özellikle dershaneye giden öğrencilerin performans, proje gibi ödevleri zaman kaybı olarak görmesi, öğrenci seviyesinin (bilgi, gelişim düzeyi, hayal gücü vb.) düşük olması, ailelerin bu konuda bilinçsiz olması ve ülke genelinde uygulanan sınavların (TEOG, YGS vb.) bu yöntemlerin uygulanmasını engellemesi gibi sorunlarla karşı karşıya kaldıkları görülmektedir. $\mathrm{Bu}$ alanda en az yaşanan sorunların ise bilgi ve beceri eksikliği ve yapılandırmacı yaklaşımın egemen olduğu yeni öğretim programına yabancılık olduğu ortaya çıkarılmıştır. $\mathrm{Bu}$ bulgulardan yola çıkılarak ölçme-değerlendirme alanındaki sorunların öğretmen kaynaklı olmadığı genellikle öğrenci ve velilerin bu konuda bilgisiz ve isteksiz olmaları, ayrıca mevcut altyapıdan kaynaklanan bir takım eksikliklerin bulunduğu söylenebilir. Ancak öğretmenler ölçme-değerlendirme alanında yaşanan sorunları kendisinden kaynaklı olarak görmemesi ile bu alanda yaşanan sorunların çözümü için en fazla oranda "eğitim fakültelerindeki eğitim programlarında bu alana yönelik derslere ağırlık verilmeli" ve "ilgili yönteme uygun ölçekler geliştirilip öğretmenlerin kullanımına sunulmalı" şeklinde öneriler sunmaları birbiriyle çelişki oluşturan ifadeler olması açısından oldukça düşündürücüdür. Araştırmadan elde edilen bulgular bu konuda yapılan araştırma bulgularıyla da paralellik göstermektedir (Akbaş ve Gençtürk, 2013; Avşar, 2009; Gelbal ve Kelecioğlu, 2007; Gömleksiz vd., 2011; Metin ve Demiryürek, 2009; Özdemir, 2009; Sağlam Arslan vd., 2009; Şaşmaz Ören ve Tatar, 2007; Öztürk, Yalvaç Hastürk ve Demir, 2013; Yıldırım ve Semerci, 2006).

Anketten elde edilen bulgulara göre araştırmaya katılan öğretmenlerin ölçme-değerlendirme araçgereç ve yöntemleri alanında yaşanan sorunların giderilebilmesi ve yaklaşımların geliştirilebilmesi açısından en çok üzerinde durdukları noktalar eğitim fakültelerindeki eğitim programlarında bu alana yönelik derslere ağırlık verilmesi gerektiği, verilen hizmet içi eğitimlerin kalitesi arttırılıp, eğitimde uygulamaya daha çok ağırlık verilmesi, ilgili yönteme uygun ölçekler geliştirilip öğretmenlerin kullanımına sunulması ve bulunulan bölge ya da okulda ölçme-değerlendirme uzmanının bulundurulması olmuştur. Bunun yanında en az oranda hizmet içi eğitim verilmeli görüşünü belirten öğretmenler bu görüşten ziyade verilen hizmet içi eğitimlerin kalitesi arttırılıp, eğitimde uygulamaya daha çok ağırlık verilmeli ifadesini daha büyük oranda dile getirmişlerdir. Buradan yola çıkılarak ölçme-değerlendirme konusunda hizmet içi eğitim verilmesi noktasında çok büyük bir sorun olmadığı görülürken, daha çok verilen hizmet içi eğitimlerin niteliği konusunda sıkıntı yaşandığı söylenebilir. Araştırma sonucunda elde edilen bulgular yapılan çeşitli araştırmalarla da paralellik göstermektedir (Akbaş ve Gençtürk, 2013; Avşar, 2009; Gelbal ve Kelecioğlu, 2007; Metin ve Özmen, 2010; Nazlıçiçek ve Akarsu, 2008; Özdemir, 2009; Sağlam Arslan vd., 2009; Şenel Çoruhlu vd., 2009).

Araştırma sonucu elde edilen bulgulardan yola çıkılarak şu öneriler ileri sürülebilir;

Yapılan araştırmada, öğretmenlerin büyük çoğunluğunun, yapılandırmacı yaklaşımın hâkim olduğu alternatif ölçme-değerlendirme alanında teorik bilgiden ziyade özellikle uygulamaya dönük eksiklikleri olduğu görülmüştür. Bu nedenle öğretmenlere konu hakkında eksikliklerini giderecek hizmet içi eğitimler verilmeli, ayrıca hâlihazırda düzenlenen hizmet içi eğitimlerin kalitesi arttırılmalı ve bu eğitimlerde uygulamaya dönük etkinliklere yer verilmelidir. Bu eğitimler düzenlenmeden önce konunun hangi alt boyutlarına yönelik eğitim verileceğinin tespiti için ihtiyaç analizi yapılmalıdır. 
Buna ek olarak hizmet içi eğitimlerin verilmesinde çevrimiçi araçlar kullanılarak daha fazla sayıda öğretmene ulaşılmasına imkân sağlanmalıdır.

Öğretmenlerin eğitim fakültelerindeki eğitim programlarında ölçme-değerlendirme alanına yönelik derslere ağırlık verilmeli görüşlerinden yola çıkılarak, öğretmen adaylarının mesleğe başladıklarında ölçme-değerlendirme alanında daha az sorun yaşamaları için eğitim fakültelerinde ölçmedeğerlendirme alanındaki derslere daha fazla ağırlık verilmeli ve uygulamaya yönelik etkinlikler yapılmalıdır.

Alternatif ölçme-değerlendirme araç-gereç ve yöntemlerinin kullanımını yaygınlaştırmak için öğretmenlerin bu yöntemlere ilişkin yeterlik hislerini arttıracak ve olumlu tutum geliştirmelerine yardımcı olacak cesaret verilmeli, buna yönelik öğretim etkinlikleri ve öğrenme yaşantıları düzenlenmelidir. Öğretmenlerin ölme-değerlendirme araç-gereç ve yöntemlerini kullanırken karşılaşacakları sorunları aşabilmeleri için bulundukları bölge ya da okulda konunun uzmanı kişilere görev verilmelidir. Ayrıca ilgili ölçme-değerlendirme araç-gereç ve yöntemlere uygun çok çeşitli ölçekler geliştirilip öğretmenlerin kullanımına sunulmalıdır.

Araştırma bulgularından hareketle öğretmenlerin ölçme-değerlendirme alanında mevcut altyapının eksik olması, öğrenci seviyesinin düşük olması, ailelerin bu konuda bilinçsiz olması ve ülke genelinde uygulanan sınavların bu yöntemlerin uygulanmasını engellemesi gibi sorunlarla karşı karşıya kaldıkları görülmektedir. Bu nedenle ölçme-değerlendirme araç-gereç ve yöntemlerinin sorunsuzca kullanılabilmesi için okul ve sınıfların mevcut altyapıları iyileştirilmeli, öğrenci ve velilerin yeni programla birlikte kullanılmaya başlayan ölçme-değerlendirme araç-gereç ve yöntemleri hakkında bilgi sahibi olmaları, bu yöntemlerin kullanışlığının ve sağlayacağı yararların farkında olmaları sağlanmalıdır. Ayrıca ülke genelinde uygulanan sınavlar, öğretim programlarında yer alan ölçmedeğerlendirme araç-gereç ve yöntemleriyle uyumlu hale getirilmelidir.

Ölçme-değerlendirme alanında çalışma yapacak araştırmacıların, özellikle alternatif yöntemlere ilişkin öğretmenlerin bakış açılarının nasıl olduğu ve bu yöntemleri kullanırken karşılaştıkları problemlerin nedenleri hakkında birebir görüşmeler ve gözlemler yaparak, bu konuda derinlemesine bilgi edinmelerinin yararlı olacağına inanılmaktadır.

\section{Kaynakça}

Akbaş, Y., ve Gençtürk, E. (2013). Coğrafya öğretmenlerinin alternatif ölçme-değerlendirme teknikleri ile ilgili görüşleri: Kullanma düzeyleri, sorunlar ve sinırlılıklar. Doğu Coğrafya Dergisi, 18(30), 331-356.

Altun, A., ve Gelbal, S. (2014). Öğretmenlerinin kullandıkları ölçme ve değerlendirme yöntem veya araçlarının ikili karşılaştırma yöntemiyle belirlenmesi. Ĕgitimde ve Psikolojide Ölçme ve Değerlendirme Dergisi, 5(1), 1-11.

Aziz, A. (2008). Sosyal bilimlerde araştırma yöntemleri ve teknikleri (4. Baskı). Ankara: Nobel Yayın Dağıtım.

Benzer, A., ve Eldem, E. (2013). Türkçe ve edebiyat öğretmenlerinin ölçme ve değerlendirme araçları hakkında bilgi düzeyleri. Kastamonu Eğitim Dergisi, 21(2), 649-664.

Böke, K. (2009). Örnekleme. K. Böke (Ed.). Sosyal bilimlerde araştırma yöntemleri içinde (ss. 103149). İstanbul: Alfa Yayınları.

Büyüköztürk, Ş., Kılıç Çakmak, E., Akgün, Ö.E., Karadeniz, Ş., ve Demirel, F. (2010). Bilimsel araştırma yöntemleri (6.baskı). Ankara: Pegem Akademi.

Büyüktokatlı, N., ve Bayraktar, Ş. (2014). Fen eğitiminde alternatif ölçme değerlendirme uygulamaları. Pegem Ĕgitim ve Öğretim Dergisi, 4(1), 103-126. 
Cansız Aktaş, M., ve Baki, A. (2013). Yeni ortaöğretim matematik dersi öğretim programının ölçme değerlendirme boyutu ile ilgili öğretmen görüşleri. Kastamonu Eğitim Dergisi, 21(1), 203-222.

Dokumaci Sütçü, N., ve Bulut, İ. (2015). Ortaokul matematik öğretmenlerinin alternatif ölçme ve değerlendirme tekniklerini kullanma düzeylerine ilişkin yeterlik algılarının değerlendirilmesi. E-International Journal of Educational Research, 6(3), 23-45.

Duban, N., ve Küçükyılmaz, E.A. (2008). Sınıf öğretmeni adaylarının alternatif ölçme-değerlendirme yöntem ve tekniklerinin uygulama okullarında kullanımına ilişkin görüşleri. İlköğretim Online, 7(3), 769-784.

Duran, M.,Mıhladız, G., ve Ballıel, B. (2013). İlköğretim öğretmenlerinin alternatif değerlendirme yöntemlerine yönelik yeterlik düzeyleri. Mehmet Akif Ersoy Üniversitesi Eğitim Bilimleri Enstitüsü Dergisi, 2(2), 26-37.

Ertürk, S. (1994). Ĕgitimde program geliştirme (8. bask1). Ankara: Meteksan.

Esen, O., Güneş, G. (2012). İlköğretim matematik öğretmenlerinin proje ve performans görevlerine ilişkin görüşleri. Turkish Journal of Computer and Mathematics Education, 3(2), 115-130.

Fidan, M., ve Sak, İ.M. (2012). İlköğretim öğretmenlerinin tamamlayıcı ölçme değerlendirme teknikleri hakkında görüşleri. Bartın Üniversitesi Ĕ̈itim Fakültesi Dergisi, 1(1), 174-189.

Fourie, I., and Van Niekerk, D. (2001). Follow-up on the portfolio assessment a module in research information skills: An analysis of its value. Education for Information, 19, 107-126.

Gelbal, S. ve Kelecioğlu, H. (2007). Öğretmenlerin ölçme ve değerlendirme yöntemleri hakkındaki yeterlik algıları ve karşılaştıkları sorunlar. Hacettepe Üniversitesi Eğitim Fakültesi Dergisi, $33,135-145$.

Gömleksiz, M.N., Yıldırım, F., ve Yetkiner, A. (2011). Hayat bilgisi dersinde alternatif ölçme değerlendirme tekniklerinin kullanımına ilişkin öğretmen görüşleri. E-Journal of New World Science Academy, 6(1), 823-840.

İslamoğlu, A.H. (2009). Sosyal bilimlerde araştırma yöntemleri (spss uygulamalı). İstanbul: Beta Yayıncilik.

Kaya, A., Balay, R., ve Göçen, A. (2012). Öğretmenlerin alternatif ölçme ve değerlendirme tekniklerine ilişkin bilme, uygulama ve eğitim ihtiyacı düzeyleri. International Journal of Human Sciences, 9(2), 1229-1259.

Metin, M., ve Demiryürek, G. (2009). Türkçe öğretmenlerinin yenilenen Türkçe öğretim programlarının ölçme-değerlendirme anlayışı hakkındaki düşünceleri. Ondokuz Mayıs Üniversitesi Ĕ̆itim Fakültesi Dergisi, 28, 37-51.

Metin, M., ve Özmen, H. (2010). Fen ve teknoloji öğretmenlerinin performans değerlendirmeye yönelik hizmet içi eğitim (HİE) ihtiyaçlarının belirlenmesi. Kastamonu Eğitim Dergisi, 18(3), 819-838.

Nazlıçiçek, N. ve Akarsu, F. (2008). Fizik, kimya ve matematik öğretmenlerinin değerlendirme araçlarıyla ilgili yaklaşımları ve uygulamaları. Eğitim ve Bilim, 33(149), 18-29.

Özdemir, S.M. (2009). Sınıf öğretmenlerinin yeni ilköğretim programlarının ölçme ve değerlendirme süreçlerinde karşılaştıkları sorunların incelenmesi. Ankara Üniversitesi Eğitim Bilimleri Fakültesi Dergisi, 42(2), 55-79.

Özenç, M. (2013). Sınıf öğretmenlerinin alternatif ölçme ve değerlendirme bilgi düzeylerinin belirlenmesi. Dicle Üniversitesi Ziya Gökalp Eğitim Fakültesi Dergisi, 21, 157-178. 
Öztürk, N., Yalvaç Hastürk, H.G., ve Demir, R. (2013). İlköğretim 4-5. sınıf fen ve teknoloji dersi öğretim programındaki ölçme ve değerlendirme yöntemlerine ilişkin öğretmen görüşleri. Dicle Üniversitesi Ziya Gökalp Ĕ̈itim Fakültesi Dergisi, 20, 25-36.

Sağlam Arslan, A., Devecioğlu Kaymakçı, Y., ve Arslan, S. (2009). Alternatif ölçme-değerlendirme etkinliklerinde karşılaşılan problemler: Fen ve teknoloji öğretmenleri örneği. Ondokuz Mayls Üniversitesi Eğitim Fakültesi Dergisi, 28, 1-12.

Semerci, Ç. (2008). Eğitimde ölçme ve değerlendirme. E. Karip (Ed.). Ölçme ve değerlendirme içinde (ss. 1-15). Ankara: Pegem Akademi.

Şahin, Ç., ve Abalı Öztürk, Y. (2014). Sınıf öğretmeni adaylarının alternatif ölçme değerlendirme yöntemlerine ilişkin görüşleri. Kastamonu Eğitim Dergisi, 22(1), 123-142.

Şahin, M.G., Boztunç Öztürk, N., ve Taşdelen Teker, G. (2015). Öğretmen adaylarının başarılarının değerlendirilmesinde tercih ettikleri ölçme araçlarının belirlenmesi. Ĕgitimde ve Psikolojide Ölçme ve Değerlendirme Dergisi, 6(1), 95-106.

Şenel Çoruhlu, T., Er Nas, S. ve Çepni, S. (2009). Fen ve teknoloji öğretmenlerinin alternatif ölçmedeğerlendirme tekniklerini kullanmada karşlaştıkları problemler: Trabzon örneği. Yüzüncü Yıl Üniversitesi Ĕ̈itim Fakültesi Dergisi, 6(1), 122-141.

Tekin, H. (2004). Ĕgitimde ölçme ve değerlendirme (17. baskı). Ankara: Yargı Yayınevi.

Tuncer, M., ve Yılmaz, Ö. (2012). Kıdem değişkeni açısından ölçme ve değerlendirme yaklaşımlarının kullanımı üzerine bir araştırma. Ĕgitim ve Öğretim Araştırmaları Dergisi, 1(4), 41-48. 